\title{
Implementasi Ijarah (Sewa Dalam Islam) Pada Lahan Pertanian Dalam Meningkatkan Pendapatan Petani Padi Di Desa Pebenaan Kec.Keritang Kab.Indragiri Hilir',
}

\author{
Sirly Deska Yana Putri \\ (Fakultas Pascasarjana, UIN Sultan Syarif Kasim Riau) \\ *Sirly1205@gmail.com
}

\begin{abstract}
Abstrak
Tujuan penelitian ini untuk mengetahui bagaimana implementasi ijarah (sewa dalam Islam) pada lahan pertanian padi, faktor yang mendukung dan menghambat implementasi ijarah, tingkat pendapatan petani dalam implementasi ijarah dan implementasi ijarah sesuai dengan syariah. Penelitian ini berlokasi di Desa Pebenaan Kec. Keritang Kab. Indragiri Hilir pada sistem ijarah (sewa dalam Islam) pada lahan pertanian padi dengan teknik pengumpulan data yaitu observasi, wawancara, studi pustaka dan dokumentasi. Jenis penelitian ini menggunakan metode kualitatif. Hasil Penelitian implementasi ijarah (sewa dalam Islam) masih bersifat kepercayaan antara pemilik lahan dan petani penyewa lahan. Faktor yang mendukung ijarah ialah jumlah lahan, tersedianya Sumber Daya Manusia sedangkan faktor penghambat ialah masih banyak petani yang belum memahami bagaimana penerapan ijarah (sewa dalam Islam) karena faktor kebiasaan dan belum adanya sosialisasi. Akan tetapi dalam implementasinya ijarah tidak bertentangan dengan Islam karena masih bersifat saling tolong-menolong dan kerelaan antara keduanya dan memenuhi syarat, kewajiban serta hak kedua belah pihak. Kesepakatan ijarah (sewa dalam Islam) dapat memenuhi kebutuhan sehari-hari petani dan hanya sebagian saja yang dapat meningkatkan pendapatan dari hasil pengelolaan lahan sewa pertanian.
\end{abstract}

Kata kunci : Implementasi, Ijarah, Meningkatkan Pendapatan Petani. 


\section{A. Pendahuluan}

Al ijarah disebut akad pemindahan hak guna (manfaat) atas sesuatu barang atau jasa dalam waktu tertentu melalui pembayaran sewa/upah, tanpa diikuti pemindahan kepemilikan barang itu sendiri. Maksud"'manfaat' ialah berguna, yaitu barang yang mempunyai banyak manfaat dan selama menggunakannya barang tersebut tidak mengalami perubahan atau musnah. Manfaat yang di ambil tidak berbentuk zatnya melainkan sifatnya dan dibayar sewa, misalnya rumah yang dikontrakkan/disewa mobil disewa untuk perjalanan. (Muhammad, 2018)

Dalam penerapannya sewa-menyewa mempunyai peranan penting dalam kehidupan manusia, agar meringankan salah satu pihak atau saling meringankan antara sesama, serta termasuk salah satu bentuk kegiatan tolong menolong yang dianjurkan oleh agama.

Seiring dengan perkembangan zaman sewa menyewa (ijarah) tidak hanya seputar pada mobil dan rumah saja, akan tetapi lahan pertanian pun ambil bagian menjadi objek dalam transaksi sewa menyewa. Menurut Imam Syaibani, Muhammad Hasan (131-189 H/748-804 M) mengemukakan bahwa pertanian adalah sektor pertama dan terpenting serta paling produktif dari segala usaha ekonomi manusia. Dia menulis " kebanyakan para syeikh dan guru besar kita berpendapat bahwa usaha pertanian lebih mulia dan lebih penting daripada perdagangan karena pertanian bersifat produktif dan lebih umum faedahnya". Dalam kenyataannya, pertanian bukanlah merupakan pekerjaan umum penduduk mekah yang suka berdagang, bahkan menjadi usaha penduduk madinah. Akan tetapi, Imam Syaibani memandang bahwa pertanian sebagai sektor ekonomi dalam pergaulan dunia. (Kaaf, 2002)

Di Kabupaten Indragiri Hilir tepat nya di Kecamatan Keritang, lahan pertanian adalah salah satu komoditas. Padi merupakan tanaman pangan yang lazim ditemukan Kecamatan Keritang dengan jenis pengairan adalah 
rawa pasang surut. Luas tanam padi sawah pada tahun 2018 adalah 7.033,5 ha dengan luas panen adalah 6.497,5 ha. Jenis padi yang ditanam adalah padi hibrida (hilir, 2019) Akan tetapi jenis benih padi yang digunakan di Desa Pebenaan ini beragam dan masa panen pun berbeda-beda.

Desa Pebenaan adalah salah satu desa yang terdapat di Kecamatan Keritang Kabupaten Indragiri Hilir. Luas wilayah Desa Pebenaan ini \pm $48,30 \mathrm{Km}$, dengan potensi lahan persawahan atau pertanian $379 \mathrm{H}$. Dari hasil pengamatan dan data yang diperoleh dari desa tersebut mayoritas penduduk di Desa Pebenaan berprofesi sebagai petani padi karena di desa ini lahan untuk bercocok tanam masih terbilang produktif. Dalam pengelolaan lahan ini petani di desa ini biasanya menggunakan sistem sewa atau ijarah jika tidak mampu untuk menggarap lahan nya sendiri.

Pada saat sekarang ini perkembangan lapangan perdagangan yang sebelumnya belum terbayangkan semakin meluas, berbagai macam perdagangan yang sebelumnya tidak diperdagangkan. Salah satu perkembangan akad perdagangan adalah tanah, yang mana pada saat sekarang ini sudah diperdagangkan, tidak sekedar diperjual belikan namun sudah disewakan untuk ditanami, karna semakin mahalnya harga tanah sehingga rakyat biasa tidak mampu untuk membelinya, hanya bisa dengan menyewa. (Lolyta, 2014)

Mengenai kesepakatan sewa atas lahan pertanian disebut juga 'kira' Demikian perjanjian sewa menyewa merupakan suatu perjanjian yang berunsurkan adanya memilik manfaat atau upah sebagai pengganti dari pihak lain.Dalam penerapan sistem ijarah (sewa) mayoritas petani di Desa Pebenaan ini biaya sewa dibayarkan dalam bentuk hasil panen yaitu padi, sedangkan pada masa Rasulullah Saw melarang sistem tersebut beliau menganjurkan untuk membayarnya dengan emas atau perak Karena hasil panen yang tidak menentu. 
Ada beberapa fenomena yang penulis temukan dan dari hasil observasi terdahulu yang berkaitan dengan masalah yang ini penulis teliti sehingga penulis tertarik untuk meneliti pelaksanaan sewa-menyewa (ijarah) pada lahan pertanian di Desa Pebenaan Kecamatan Keritang Kabupaten Indragiri Hilir, diantaranya karena adanya ketidakpastian hasil yang diperoleh oleh para petani penggarap sedangkan hasil sewa telah ditetapkan di muka, sistem pembayaran upah masih menggunakan hasil lahan sedangkan rasulullah telah melarang hal tersebut. Di Desa Pebenaan sistem pertanian masih menggunakan 1 kali panen dalam 1 tahun dikarenakan di daerah ini sistem pengairan lahan pertanian menggunakan tadah hujan atau menunggu waktu musim hujan tiba bukan dengan aliran irigasi.

Impelementasi sewa lahan pertanian di desa Pebenaan tidak semuanya para petani mengerti tata cara pelaksanaan yang sesuai dengan Islam, karena tidak pernah adanya sosialisasi bagaimana sebaiknya kerja sama yang sesuai dan tidak saling menguntungkan. Banyak petani yang masih keberatan dengan sistem sewa di karena hasil yang diperoleh tidak tentu akan tetapi pembayaran sewa telah ditetapkan. Berdasarkan wawancara menurut bapak husein"'penetapan sewa di awal di Desa Pebenaan telah menjadi kebiaasan petani karena harga sewa sama disetiap tempatnya yang ditetapkan berdasarkan ukuran depa, akan tetapi karena jumlah yang dihasilkan tidak diketahui adakala nya hasil yang diperoleh tidak sesuai dengan biaya yang dikeluarkan akan tetapi sewa tetap sama seperti pemilik lahan yang bapak sewa, pemilik tidak mau mengurangi biaya sewanya.

\section{B. Metodologi}

Penelitian yang digunakan adalah penelitian kualitatif dan karena peneliti lebih cenderung mengunakan analisa data dalam memaparkan bagaimana strategi pemasaran yang digunakan dan apa saja hambatan serta 
yang mendorong agar dapat meningkatkan anggota. Metode penelitian kualitatif dapat di artikan sebagai metode penelitian yang berlandaskan pada filsafat postpositivisme, digunakan untuk meneliti pada kondisi obyek yang alamiah, (sebagai lawannya adalah eksperimen) dimana peneliti sebagai instrumen kunci, teknik pengumpulan data dilakukan secara trigulasi (gabungan), analisis data bersifat induktif/kualitatif, dan hasil penelitian kualitatif lebih menekankan makna dari pada generalisasi.

Penelitian di lakukan di Desa Pebenaan Kec. Keritang Kab. Indragiri Hilir pada implementasi ijarah (sewa dalam Islam) pada lahan pertanian yang dikelolah oleh petani padi karena kesepakatan sewa menyewa lahan pertanian padi menjadi salah satu aktivitas ekonomi di Desa Pebenaan ini. Adapun penelitian ini dilakukan dimulai pada januari 2020 sampai selesai.

Dalam penelitian ini sumber data diperoleh dari data primer dan data sekunder. Data primer adalah data yang diperoleh dari hasil penelitian dengan observasi dan wawancara langsung dengan narasumber berdasarkan permasalahan yang diteliti yaitu petani, pemilik lahan. Data sekunder adalah data yang diperoleh dari data yang telah dikumpulkan berkaitan dengan permasalahan yang diteliti baik itu dari buku, jurnal, koran, media sosial dan tokoh setempat yang mengetahui tentang penelitian ini.

\section{Hasil}

Hasil penelitian yang disajikan dalam bagian ini adalah hasil "bersih". Proses analisis data seperti perhitungan statistik dan proses pengujian hipotesis tidak perlu disajikan. Hanya hasil analisis dan hasil pengujian hipotesis yang perlu dilaporkan. Tabel dan grafik dapat digunakan untuk memperjelas penyajian hasil penelitian secara verbal. Tabel dan grafik harus diberi komentar atau di bahas. 
Untuk penelitian kualitatif, bagian hasil memuat bagian-bagian rinci dalam bentuk sub topik-sub topik yang berkaitan langsung dengan fokus penelitian dan kategori-kategori.

Dalam implementasi akad ijarah (sewa dalam Islam) petani di Desa Pebenaan masih menggunakan sistem kepercayaan sehingga proses pelaksanaan sewa lahan hanya sekedar lisan saja tanpa adanya pihak notaris atau bukti tertulis untuk menguatkan kesepakatan tersebut. Sistem saling percaya antara kedua pihak memudahkan untuk melaksanankan sewa menyewa dikarenakan masih banyaknya yang tidak dapat memahami baca dan tulis bahkan masih ada yang berkomunikasi menggunakan bahasa suku nya sehingga jika dilakukan perjanjian secara tertulis masih membingungkan bagi mereka karena kebiasaan petani tersebut secara lisan.

Dalam sewa menyewa lahan pertanian ini jenis tanaman yang dikelolah ialah jenis tanaman padi dengan beragam jenis bibit padi. Dengan keberagaman jenis bibit padi yang ditanam pemilik lahan tidak ikut ambil dalam penentuan jenis padi apa yang di tanam akan tetapi jenis tanaman yang di tanam pemilik lahan berhak untuk memberi tahu pada awal kesepakatan bahwa tanaman yang harus di tanam adalah padi.

Berdasarkan hasil wawancara kepada para petani penulis merangkum jawaban para responden, ada beberapa langkah yang disepakati antara penyewa lahan dan petani pemilik lahan pertanian adalah sebagai berikut :

1. Petani yang ingin menyewa lahan pertanian mendatangi petani yang memiliki lahan untuk menawarkan diri mengelolah lahan pertanian tersebut. Ketika pemilik lahan menyetujui penawaran tersebut, maka kesepakan sewa telah di mulai. Petani yang menyewa lahan pertanian tesebut menjelaskan jenis tanaman padi apa yang akan ditanam di lahan tersebut. Di Desa Pebenaan ini karena mayoritas 
lahan pertanian di tanami padi jadi penyewa tidak perlu menjelaskan jenis tanaman apa yang di tanam akan tetapi jenis padi yang akan di tanam saja di jelaskan.

2. Ucapan serah terima kesepakatan antara pemilik lahan dengan petani yang ingin menyewa lahan tersebut yang bisa disebut juga dengan ijab dan qabul. Ucapan serah terima kesepakatan sewa menyewa lahan tidak secara formal di ucapakan akan tetapi dari kata-kata dan ucapan antara keduanya ada hal yang mengandung ijab dan qabul.

Dalam pengucapan kesepakatan sewa menyewa antara pemilik lahan dan petani penyewa lahan tidak semuanya ucapan sesuai dengan ijab qabul sesuai syariah akan tetapi mereka mengatakan berdasarkan bahasa sehari-hari baik itu bahasa Indonesia maupun bahasa para suku masing-masing. Meskipun seperti itu mereka memahami semua ucapannya karena telah menjadi bahasa keseharian di Desa Pebenaan tersebut. Seperti “'pattamparika galungmu ujama lettu pura maneng (Bahasa Bugis)', artinya saya sewa ladang bapak untuk dikerjakan atau dikelolah sampai selesai dan waktu berakhir. Itu adalah salah satu ucapan yang dikatakan petani yang akan menyewa lahan pertanian tersebut. Kemudian dibalas kembali ucapan tersebut oleh pemilik lahan seperti''iyyek alani ditampari galungku lettu pura tajama maneng, tampana pada meto tauwe labe'e artinya sewa lah tanah saya sampai selesai dan batas waktu berakhir dengan jumlah sewa sama seperti ketentuan orang lain atau jumlah sewa yang biasa dibayarkan petani. ${ }^{1}$ Ucapan-ucapan tersebut sudah biasa di ucapakan para petani dan pemilik lahan karena mereka telah memahi satu sama lain maksud dari ucapan tersebut.

\footnotetext{
${ }^{1}$ Baba (Petani Padi), Wawancara, tgl 16 April 2020
} 
3. Pemilik lahan kemudian menjelaskan spesifikasi lahan yang akan disewakan dengan menjelaskan ukuran luas lahan tersebut. Sistem penentukan ukuran masih bersifat tradisional seperti pengukuran menggunakan 1 depa yaitu ukuran bentangan tangan orang dewasa.

4. Selanjutnya pemilik dan penyewa lahan pertanian menentukan berapa jumlah sewa yang harus dibayarkan oleh petani penyewa lahan tersebut. Biasanya proses pembayaran ini berdasarkan kebiasaan dalam pertanian yang ada di Desa Pebenaan. Pembayaran sewa di ukur berdasarkan 1 depa, sedangkan dalam 1 depa ukuran sewa dalam pertanian ini ialah 3, 4 dan 5 kaleng padi. Berdasarkan hasil dari wawancara peneliti dilapangan jumlah pembayaran sewa lahan pertanian padi ada beberapa parit yang jumlah ukuran pembayaran sewa nya berbeda. Menurut bapak arpan" perbedaan jumlah ukuran sewa lahan pertanian di Parit Kepol ini mayoritas adalah 4 kaleng karena ukuran parit disini lebih panjang sehingga jumlah sewa lebih tinggi dari parit sebelah'. Ada pula di parit pinang jumlah sewa per depa adalah 5 kaleng karena sudah ketentuan seperti itu, meskipun seperti itu sewa menyewa tetap telaksana karena di area parit pinang disini memang seperti itu ketentuannya.

5. Pembayaran hasil sewa di sepakati bahwa jumlah sesuai dengan jumlah lahan sewa dan dibayarkan hasil sewa ketika hasil panen telah selesai. Sewa yang dibayarkan petani berbentuk hasil pertanian yaitu padi dikarenakan jika pembayaran dengan padi. Penyewa lahan cukup mengantarkan sewa lahan tersebut ke gudang padi. Gudang padi adalah sebuah tempat penampungan padi para petani dan sebagai tempat pengelolaan padi menjadi beras. 
Dalam melakukan wawancara ada terdapat perbedaan pembayaran ujrah atau pembayaran sewa lahan pertanian menurut responden", pembayaran ujrah dilakukan disaat awal yakni ketika kesepakatan telah dilakukan dan hasil pembayaran sewa telah ditentukan maka penyewa lahan dapat membayar sewa lahan pertanian terlebih dahulu karena permintaan dari pemilik lahan, alasannya karena pemilik lahan membutuhkan hasil sewa tersebut.

Karena benda atau barang yang menjadi objek sewa-menyewa di Desa Pebenaan dan menjadi objek penelitian penulis adalah lahan pertanian padi. Berdasarkan hasil wawancara ada beberapa ketentuan syarat lahan yang pertanian yang menjadi objek sewa menyewa sebagai berikut:

1. Lahan pertanian padi yang menjadi objek sewa menyewa dapat dipergunakan dan dikelolah sesuai dengan penggunaannya

2. Lahan pertanian padi yang disewa dapat diterima hasil pengelolaannya untuk petani penyewa.

3. Lahan pertanian padi yang di sewa dapat dipergunakan dengan jangka lama sehingga dapat dipergunakan hingga sewa menyewa berakhir.

Kegiatan ijarah (sewa dalam Islam) antara pemilik lahan dan petani yang menyewa menimbulkan hak dan kewajiban antara keduanya antara lain sebagai berikut:

1. pemilik lahan yang menyewakan dapat menerima hasil atau upah terhadap apa yang telah disewakan.

2. Orang yang menyewa wajib membayar imbalan atau upah terhadap apa yang telah disewa.

3. Pembayaran yang dilakukan sesuai dengan harga yang telah disepakati oleh kedua belah pihak

4. Pemilik lahan pertanian padi menjelaskan ukuran lahannya 
5. Orang yang menyewa berhak atas manfaat dari objek sewa. Yaitu berhak memanfaatkan, mengelolah dan menggarap lahan pertanian padi tersebut sampai waktu sewa berakhir

6. Bagi petani penyewa resiko yang akan terjadi ketika dalam masa pengelolaan atau pada saat memanen hasil pertanian sepertinya terjadi kegagalan panen sehingga hasilnya merugi maka petani penyewa menanggung resiko tersebut sendiri

\section{Pembahasan}

1. Faktor yang mendukung dan menghambat Implementasi Ijarah (sewa dalam Islam) pada Lahan Pertanian di Desa Pebenaan

Kegiatan sewa menyewa lahan pertanian padi dalam pengelolaan dan implementasinya terdapat beberapa faktor yang mendukung sehingga kesepakatan ijarah (sewa dalam Islam) dapat di terapakan dan dilaksanakan. Selama masa penelitian di lapangan peneliti menemukan faktor-faktor apa saja yang mendukung terjadinya sewa menyewa yakni sebagai berikut:

a. Lahan

Sumber daya alam yaitu lahan atau tanah pertanian di Desa Pebenaan bisa dikatakan luas karena hamparan lahan pertanian yang masih banyak di kelolah oleh petani. Penggunaan lahan pertanian di desa Pebenaan pada umumnya digunakan untuk menanam padi dengan bermacam jenis bibit padi.

Di Desa Pebenaan istilah lahan disebut juga ladang, masyarakat setempat menyebut ladang. Jenis ladang di Desa Pebenaan masih jenis ladang kering sehingga jenis tanaman yang ditanam harus bersifat lembab karena lahan pertanian tinggi. Penggunaan ladang hanya dapat dikelolah ketika pada musim hujan karena pada musim hujan ladang-ladang petani dapat di aliri air dari air hujan. 
b. Sumber Daya Manusia

Ketersedian sumber daya manusia yang menjadi faktor pendukung di Desa Pebenaan adalah petani karena mayoritas pekerjaan masyarakat desa setempat adalah petani. Petani yang dimaksud disini bukan saja mereka yang bercocok tanam di ladan sendiri akan tetapi mereka yang mengupah atau menyewa lahan untuk dikelolah bisa disebut juga petani. Kepahaman mereka dalam hal pertanian sudah mereka tekuni dari kecil hingga sekarang dan mereka pelajari dari orang tua mereka.

Petani yang bermukim di Desa Pebenaan tidak hanya kaum lelaki saja akan tetapi kaum wanita juga banyak yang menjadi petani bahkan para pemuda dan pemudi yang ikut membantu orang tua telah paham bagaimana mengeluti profesi petani di desa Pebenaan ini.

Ijarah (sewa dalam Islam) adalah salah satu kegiatan yang telah menjadi salah satu dalam kegiatan perekonomian apalagi dalam sektor pertanian lahan padi. Petani di Desa Pebenaan telah menerapakan sistem ijarah (sewa dalam Islam) berdasarkan adat kebiasaan setempat dengan cara tradisional. Meski mayoritas masyarakat bahkan petani adalah muslim mereka belum memahami bagaimana ijarah (sewa dalam Islam) yang sesuai dengan ajaran Islam.

Adapun mereka yang mengetahui tentang sistem ijarah (sewa dalam Islam) mereka beranggapan kegiatan tersebut sama saja dengan kegiatan sewa-menyewa jika diantara kedua belah pihak tidak ada yang dirugikan. Tetapi ketidaktahuan ini maka penulis berusaha mengangkat problematika untuk membedakan sistem penggunaannya dengan sosialisasi secara langsung kepada petani. 
2. Pendapatan Petani Penyewa Lahan dalam Implementasi Ijarah (Sewa dalam Islam)

Tuntutan ekonomi yang semakin tinggi dan banyaknya biaya yang dikeluarkan untuk memenuhi kebutuhan keluarga sehingga pendapatan hasil dari pengelolaan lahan sewa tidak setiap panen dapat disisihkan untuk menabung. Karena dalam mengelolah lahan pertanian tersebut tidak sekedar menggunakan tenaga saja akan tetapi butuh modal dan bantuan orang lain untuk mengelolahnya.

Biasanya petani menyewa lahan tidak semuanya dapat mengelolah banyak lahan dikarenakan jumlah lahan sewa bukan petani yang menentukan akan tetapi ialah pemilik lahan. Dari beberapa kumpulan hasil wawancara jawaban yang diperoleh penulis hampir sama tentang pendapatan hasil panen yang dapat ditabung bagi mereka yang menyewa lahan beberapa depa saja. Berdasarkan hasil wawancara terdapat pemaparan para petani mengenai hasil pendapatan panen padi setelah dikurangi segala pengeluaran menurut bapak hamid' karena saya tidak mempunyai lahan sendiri untuk dikelolah maka dari itu saya menyewa lahan petani lain, dari hasil pendapatan mengelolah sewa lahan tersebut selama hampir 5 tahun saya belum mampu untuk menyisihkan untuk membeli lahan sendiri karena biaya hidup keluarga dari hasil panen dan untuk biaya sekolah anak-anak saya. Apalagi jumlah lahan pertanian yang saya sewa hanya 20 depa.

Dalam sewa lahan pertanian ini ada beberapa informan mengatakan jika pelaksanaan sewa lahan hanya untuk sekedar perputran modal yang dikelolah menjadi padi karena hasil yang diperoleh hanya habis untuk biaya sehari-hari. Keikutsertaan anggota keluarga dalam mengelolah lahan pertanian yang disewa termasuk salah satu pendapatan dikarenakan penyewa lahan tidak perlu meminta bantuan kepada orang lain dengan imbalan sesuai apa yang dikerjakan. Keikutsertaan anggota 
keluarga dapat meminimalisir pengeluaran sehingga dapat memaksimumkan pendapatan. Berdasarkan pemaparan bapak kamir', saya tidak meminta bantuan orang lain untuk mengelolah lahan pertanian tersebut akan tetapi saudara dan orang tua saya ikut membantu, jadi biaya yang saya keluarkan hanya biaya perawatan padi, biaya mesin dan biaya sewa. Sehingga hasil panen dapat saya tabung untuk membeli kebun dan ditambah pula lahan yang saya sewa ada 50 depa.

Berdasarkan hasil dari jawaban wawancara petani beragam maka penulis mengelompokkan jawaban tersebut dalam sebuah tabel di bawah ini :

Tabel. 1

Klasifikasi Pendapatan (menabung) Petani

\begin{tabular}{|l|l|c|c|}
\hline No & \multicolumn{1}{|c|}{$\begin{array}{c}\text { Alternatif Jawaban Informan } \\
\text { (Petani Penyewa) }\end{array}$} & Frekuensi & Persentase \\
\hline 1 & Tidak Dapat Menabung & 77 & $52 \%$ \\
2 & Dapat Menabung & 63 & $48 \%$ \\
\hline & Total & 130 & $100 \%$ \\
\hline
\end{tabular}

Sumber data: Olahan Data Primer

Berdasarkan tabel di atas dapat disimpulkan bahwa dari beberapa informan sekitar $52 \%$ petani tidak mampu menabung. Ada beberapa alasan para petani yang tidak dapat menabung yakni:

a. Hasil panen yang kurang

b. Biaya pengelolaan yang banyak

c. Tanggungan biaya hidup yang besar

Sedangkan $48 \%$ dari petani yang penulis wawancarai dapat menabung dikarenakan beberapa hal yakni:

a. Jumlah lahan yang disewa luas

b. Hasil panen sesuai dengan proses yang dikerjakan 
c. Keikutsertaan anggota keluarga dalam mengelolah dapat meminamilisir pengeluaran

d. Pekerjaan nya tidak sekedar bertani, karena memiliki pekerjaan lain seperti berkebun.

3. Implementasi Ijarah (sewa dalam Islam) Lahan Pertanian Padi Sesuai Syariah

Ijarah (sewa dalam Islam) pada lahan pertanian telah lama diterapkan di Desa Pebenaan ini karena profesi masyarakat setempat adalah petani maka dari itu karena bagi petani yang tidak memiliki lahan maka petani melakukan kesepakatan ijarah (sewa dalam Islam) untuk dapat dikelolah memenuhi kebutuhan ekonomi. Dengan pembayaran yang telah ditetapkan di awal kisaran 3-4 kaleng padi dalam 1 depa. Kegiatan sewa disini sangat membantu antara keduanya.

Meski dalam pengelolaan lahan terkadang terjadinya gagal panen akan tetapi petani tetap melakukan kesepakatan sewa ini karena mereka menganggap pertanian adalah mata pencaharian utama mereka. Akan tetapi dengan sistem kepercayaan tanpa ada hitam di atas putih.

Ijarah (sewa dalam Islam) lahan pertanian padi telah menjadi salah satu kesepakatan dalam aktivitas ekonomi yang telah menjadi salah satu mata pencaharian masyarakat di Desa Pebenaan. Menurut bapak firzan' 'kegiatan sewa menyewa lahan pertanian boleh saja diterapkan asalakan untuk kemaslahatan bersama dan tanpa ada pihak-pihak yang dirugikan.

Kesepakatan sewa-menyewa yang dilakukan bukan sekedar hanya kontrak perjanjiaan bersifat materil akan tetapi bersifat nonmaterial karena adanya prilaku saling tolong-menolong (ta'awun) antara pemilik lahan dan petani yang sama-sama membutuhkan karena petani penyewa lahan untuk dikelolah dan pemilk lahan butuh jasa atau orang lain untuk 
mengelolahnya. Sifat ta'awun disini juga di anjurkan oleh Allah SWT dalam firmannya QS. Al-Maidah: 2

Artinya: dan tolong-menolonglah kamu dalam (mengerjakan) kebajikan dan taqwa, dan janganlah tolong-menolong dalam berbuat dosa dan permusuhan. Bertakwalah kepada Allah, sungguh Allah sangat berat siksanya. (RI, 2014)

\section{E. Kesimpulan}

Dari uraian hasil observasi dan wawancara langsung yang dilakukan penulis berkaitan implementasi ijarah (sewa dalam Islam) pada lahan pertanian padi di Desa Pebenaan Kec. Keritang Kab.Indragiri Hilir penulis simpulkan sebagai berikut:

1. Implementasi atau penerapan ijarah (sewa dalam IslamI pada lahan pertanian padi telah menjadi salah satu kegiatan yang dilakukan antara pemilik lahan dan petani penyewa untuk mengelolah lahan produktif. Penerapan sewa menyewa telah ada sejak dahulu sistem kesepakatannya masih bersifat saling percaya dan tolong-menolong.

2. Pada penerapan ijarah ini faktor yang mendukung kesepakatan ini sumber daya manusia yang memiliki keahlian dibidang pertanian serta lahan pertanian yang mendukung sehingga meski para petani tidak memiliki lahan sendiri akan tetapi mereka tetap bisa bertani dengan melakukan kesepakatan sewa kepada pemilik lahan yang bersedia menyewakan lahannya.

3. Sedangkan faktor yang menghambat penerapan ijarah (sewa dalam Islam) yang sesuai ajaran Islam karena belum pernah adanya sosialisasi bagaimana penerapan ijarah yang sesuai meski mayoritas petani adalah muslim hanya segelintir yang mengetahuinya.

4. Pendapatan petani penyewa lahan pertanian dari hasil panen berdasarkan hasil wawancara dapat disimpulkan bahwa hasil dari pengelolaan lahar 
pertanian sebagian besar hanya dapat memenuhi kebutuhan sehari-hari, karena biaya perawatan dan pengelolaan lahan membutuhkan biaya besar apalagi jika terjadi gagal panen karena faktor cuaca atau gangguan hama sehingga hasil yang diperoleh tidak imbang.

5. Dalam pandangan ekonomi sesuai syariah penerapan ijarah (sewa dalam Islam) ini masih sesuai dengan ketentuan Islam karena sistem saling tolong menolong. Penerapan sewa pada lahan pertanian berdasarkan pengamatan akademisi dan pemuka agama diperbolehkan selama untuk kemaslahatan bersama.

\section{Referensi}

Hilir, B. I. (2019).

Kaaf, A. Z. (2002). Ekonomi Dalam Prespektif Islam. Bandung: Pustaka Setia.

Lolyta. (2014). Sewa Menyewa Tanah Menurut Ibnu Hazm Dalam Prespektif Fiqh Muamalah. Hukum Islam, Vol.XIV , 127.

Muhammad. (2018). Bisnis Syariah. Depok: PT. Rajawali Press.

RI, K. A. (2014). Al-Qur'an dan Terjemahnya Al-Ikhlas. Jakarta: Samad. 